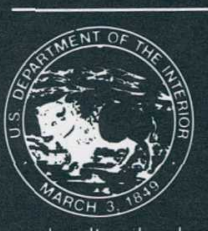

As the Nation's principal conservation agency. the Department of the Interior has responsibility for most of our nationally owned public lands and natural and cultural resources. This includes fostering sound use of our land and water resources: protecting our fish. wildlife. and biological diversity: preserving the environmental and cultural values of our national parks and historical places: and providing for the enjoyment of life through outdoor recreation. The Department assesses our energy and mineral resources and works to ensure that their development is in the best interests of all our people by encouragirig stewardship and citizen participation in their care. The Department also has a major responsibility for American Indian reservation communities and for people who live in island territories under U.S. administration

\section{The U.S. Geological Survey Library System}
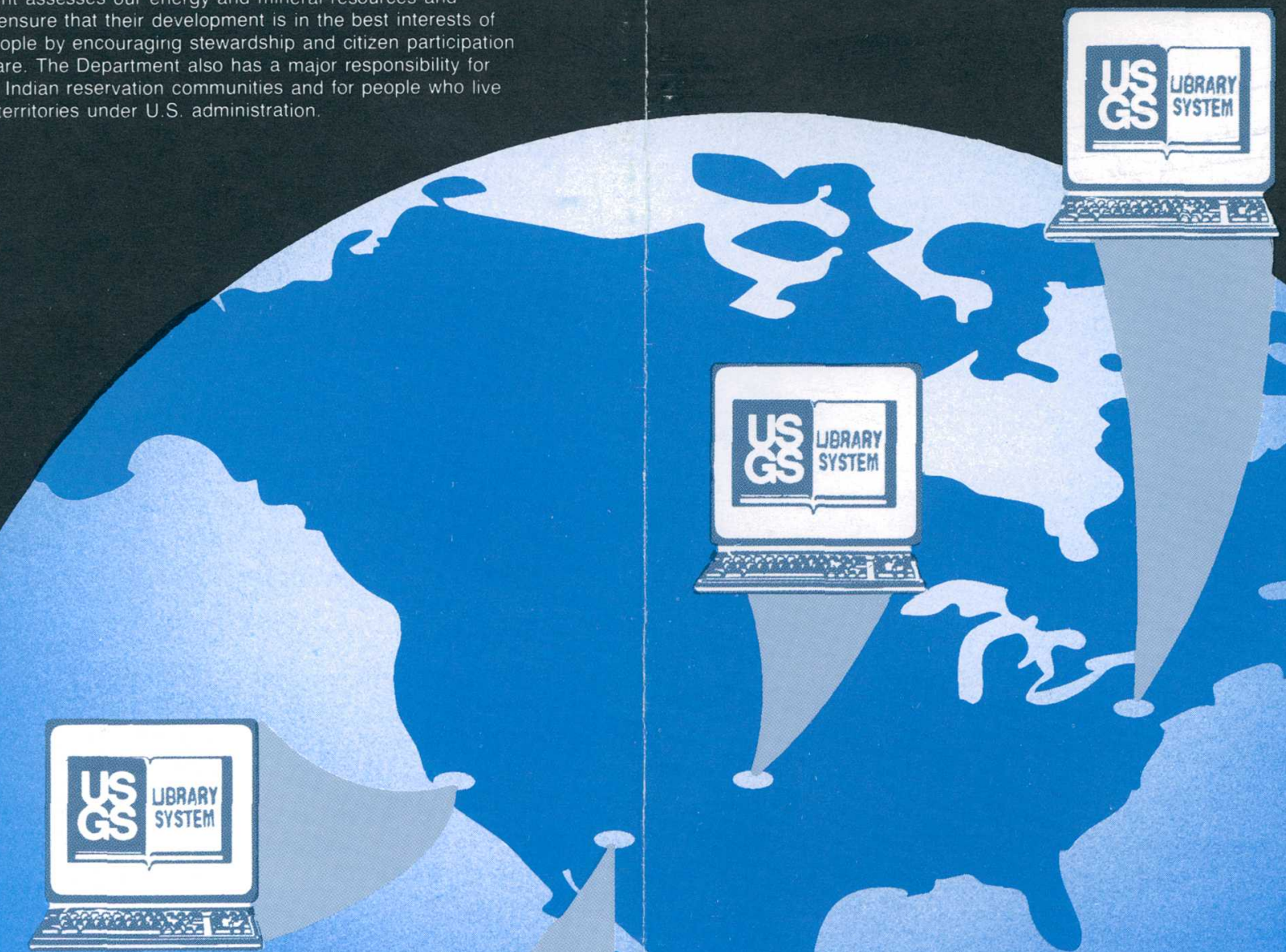


\section{The U.S. Geological Survey Library System}

The U.S. Geological Survey Library, established in 1882, is one of the largest earth science libraries in the world. The Library System consists of the headquarters library in Reston, Virginia, and three branch libraries in Denver, Colorado; Flagstaff, Arizona; and Menlo Park, California.

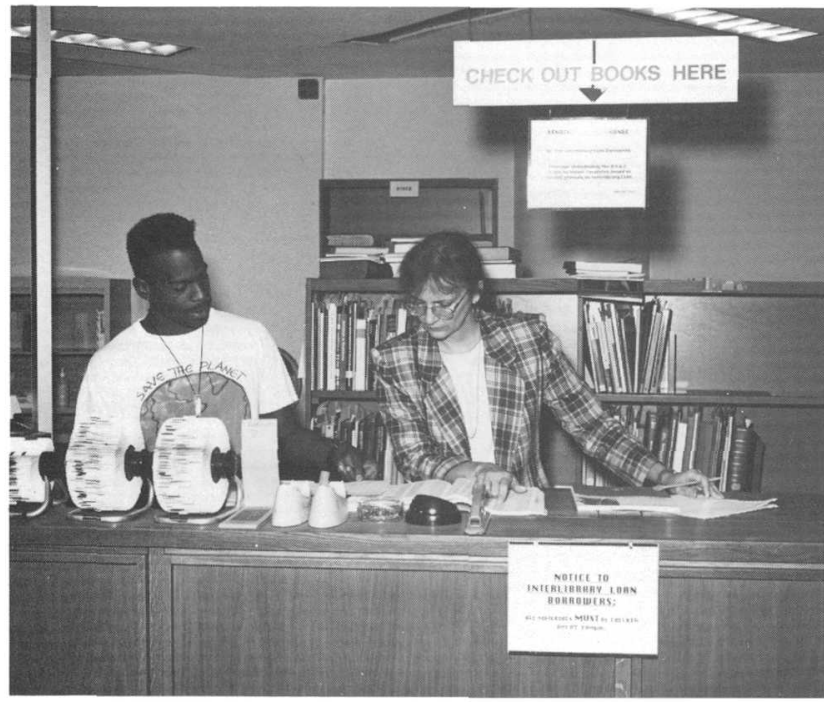

\section{Access}

Libraries are open to the public Monday through Friday. Reference service is provided at all library locations. Certain materials are available to other libraries through interlibrary loan. The USGS Library System contributes to several international bibliographic databases and provides USGS publications to other scientific libraries and organizations through exchange agreements.

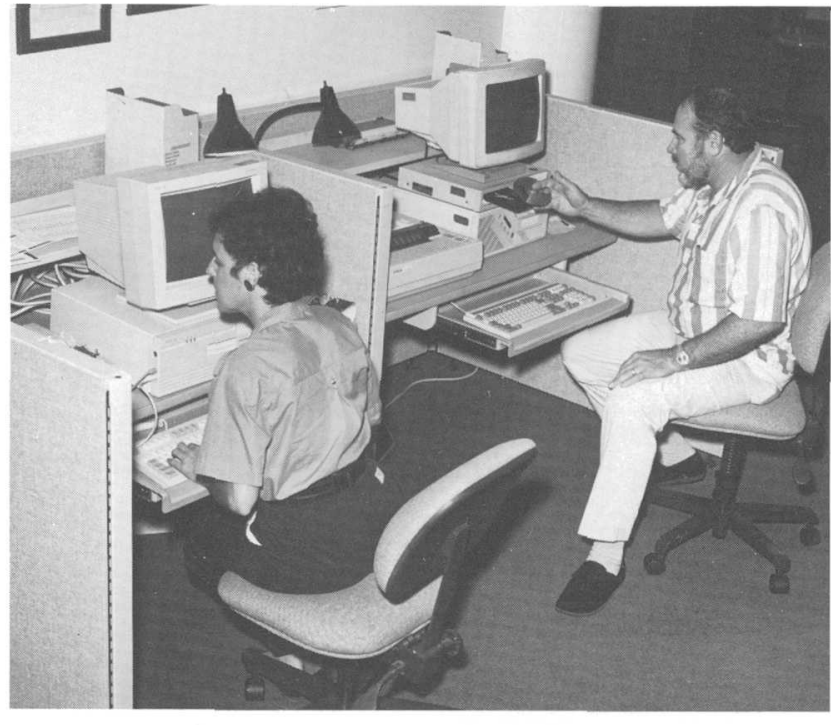

\section{Holdings}

The Library System contains more than 1 million books and journals and more than 450,000 maps covering all aspects of the earth sciences and related subjects. Subjects collected extensively include

Cartography

Earthquakes and

seismology

Geochemistry

Geology

Ground water

Hydrology

Mineral resources

Mineralogy

Holdings include USGS publications and materials from sources all over the world, including State and foreign geological surveys, geological and other scientific societies, museums and academic institutions, and government scientific agencies. Materials are received through exchange, gift, and purchase. The Libraries in Reston and Menlo Park are designated as official depositories for selected U.S. Government publications.

\section{Special Collections}

\section{Reston}

The Cartographic Information Center contains more than 290,000 map sheets and their accompanying texts, from all parts of the world. The center also provides information about maps, mapping, and related subjects focusing on earth science topics.

\section{Denver}

The Field Records Library contains more than 20,000 field notebooks or files, 4,600 map groups, 70,000 aerial photographs, and other material relating to projects carried out since 1870 by the USGS and its predecessor surveys.

The Photographic Library consists of about 300,000 photographs taken during geologic studies of the United States and its territories by the USGS and its predecessor surveys from 1869 to the present. Reproductions of photographs are available for purchase.

\section{Menlo Park}

The Aerial Photography Collection includes more than 250,000 aerial photographs, primarily of California during the early 1960's and 1970's. The collection also contains still photographs and about 25,000 slides on earth science subjects, plus a large number of videotapes.

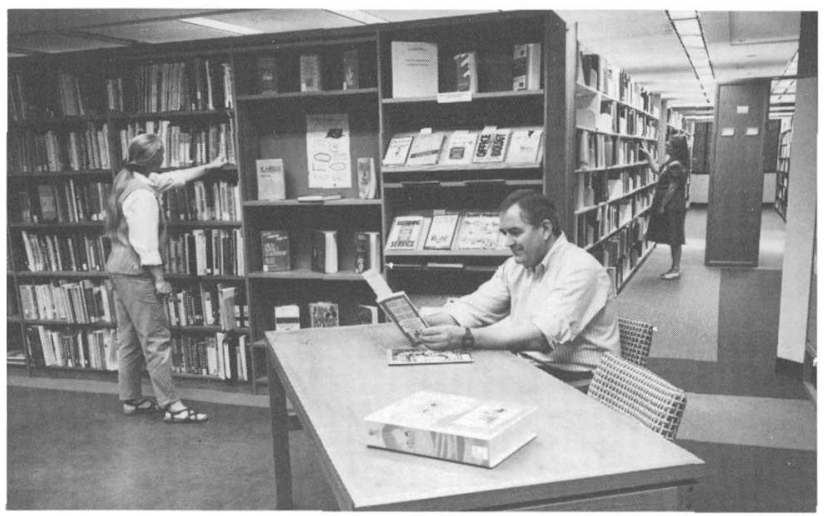


Qdidresses and Telephome Numbers

U.S. Geological Survey Library

National Center, MS 950

12201 Sunrise Valley Drive

Reston, VA 22092

(703) 648-4302 Reference

(703) 648-4105 TTY

(703) 648-5555 Cartographic Information Center (MS 952)

U.S. Geological Survey Library

Box 25046 Federal Center, MS 914

Denver, CO 80225-0046

(303) 236-1000 Reference

(303) 236-0998 TTY

(303) 236-1005 Field Records

(303) 236-1010 Photographs

U.S. Geological Survey Library

2255 North Gemini Drive, MS 9270

Flagstaff, AZ 86001-1698

(602) 556-7008 Reference

U.S. Geological Survey Library

345 Middlefield Road, MS 955

Menlo Park, CA 94025-3591

(415) 329-5027 Reference

(415) 329-5094 TTY

(415) 329-5009 Photographs

This publication is one of a series of general interest publications prepared by the U.S. Geological Survey to provide information about the earth sciences, natural resources, and the environment. To obtain a catalog of additional titles in the series "General Interest Publications of the U.S. Geological Survey," write:

U.S. Geological Survey

Branch of Distribution

P.O. Box 25286

Denver, CO 80225 